\title{
The Effectiveness of the Cooperative Problem-Based Learning in Improving the Elementary School Students' Critical Thinking Skills and Interpersonal Intelligence
}

\author{
Khalis Amrullah $^{1} *$, S. Suwarjo ${ }^{1}$ \\ ${ }^{1}$ Department of Primary Education, Graduate School of Universitas Negeri Yogyakarta. \\ Jalan Colombo No. 1, Karangmalang, Yogyakarta, 55281, Indonesia. \\ *Corresponding Author. Email: khalis.amrullah@gmail.com \\ Received: 18 October 2016; Revised: 27 December 2017; Accepted: 10 January 2018
}

\begin{abstract}
This research aims to find out the effect of the cooperative problem-based learning on the improvement of the critical thinking and interpersonal intelligence of the fifth-grade students. This research was a quasi-experiment with the pretest-posttest control group design. The subjects were all fifth-grade students of SDN Liang Anggang 1, Pandahan 1, and Pandahan 2, Bati-Bati District of South Kalimantan in the second semester of the academic year 2015/2016. Data collection techniques that used were test and scale technique. The test was used to find out the critical thinking and the scale were used to find out the interpersonal intelligence.The hypothesis was tested using t-test and MANOVA with 0.05 significant levels. The result of this research shows that the use of the cooperative problem-based learning model in natural science teaching is effective in improving critical thinking and interpersonal intelligence of the fifth-grade students. Based on the result of t-test in posttest, the experimental I and II with control group show that the sig. $<0.05$ and the result of the MANOVA in the experimental I and II with control group show that the significant value $0.000<$ 0.05 .
\end{abstract}

Keywords: cooperative problem-based learning, critical thinking, interpersonal intelligence

How to Cite: Amrullah, K., \& Suwarjo, S. (2018). The effectiveness of the cooperative problem-based learning in improving the elementary school students' critical thinking skills and interpersonal intelligence. Jurnal Prima Edukasia, 6(1), 66-77. doi:http://dx.doi.org/10.21831/jpe.v6i1.11253

Permalink/DOI: http://dx.doi.org/10.21831/jpe.v6i1.11253

\section{Introduction}

An essential mission in qualified human resources development has been declared in National Law No.20 Year 2003 article 3 stating that:" The National Education functions to develop the capability, character, and civilization of the nation for enhancing its intellectual capacity, and is aimed at developing learners potentials so that they become persons imbued with human values who are faithful and pious to one and only God; who possess morals and noble character; who are healthy, knowledgeable, competent, creative, independent; and as citizens, are democratic and responsible".

The development of students' capability in natural science subject is one way to prepare human resources to face the 21 st century which is widely known as globalization and industrialization. Trilling \& Fadel (2009, p. 48) explained that a set of 21 st-century skills are critical thinking and problem solving, communication and collaboration, creativity and innovation.

The natural science subject learning that is based on content standard will create students who have body of knowledge; process standard will create students who have scientific skills, thinking skills, strategy of thinking; science inquiry standard will create students who are able to think creatively and critically; assessment standard will evaluate students humanly, meaning that they are evaluated according to their own experiences during the learning process (authentic assessment).

However, reality does not meet expectation. Based on an observation of natural science subject learning in the fifth graders of SDN Liang Anggang 1 Bati-Bati District of South Kalimantan in October 2015 that still used KTSP (The School-Based Curriculum), some 
Jurnal Prima Edukasia, 6 (1), January 2018 -67

Khalis Amrullah, S. Suwarjo

problems were identified as followings. First, 20 out of 33 students seemed so confused that they did not know what they should have done when they were asked to do a science experiment. Students were unable to identify and solve problems as well as draw conclusions on presented materials taught by the teacher.

Second, there were some students who forgot to bring their books during the learning process, yet their seatmates did not share their book with them. They were willing to share when they were asked to do so by their teacher. Furthermore, some other students did not want to lend their stationery to their classmates although they had more. Furthermore, in the break time, students tended to be insensitive and selfish, mingled only with their own groups, and did not want to mingle with others outside their own groups.

Based on those problems, there was an essential problem that should be the main focus. It was a lack of students' critical thinking skills and interpersonal intelligence. Those skills play an important role in the students' learning goals achievement and daily lives.

Critical thinking skill is an essential skill in life, job, and functions effectively in all aspects of human life. It has been a primary objective of education. Dewey (Fisher, 2001, p. 2) explained that critical thinking is an active process which one does not only take others' ideas and information for granted (passively), yet he also thinks deeper through investigating, interpreting and drawing conclusions. A critical thinker will look for better conclusions, beliefs, and decisions by having values for his mental strength, such as self-autonomy, curiosity, humbleness, and a good reasoning recognition.

Besides, another important skill in the 21 st century is communication and collaboration. Human is social beings meaning that our lives require interactions with other people. Interpersonal intelligence is a basic thing to build a relationship with others. Gardner (2011, p. 7) stated that interpersonal intelligence is an ability to understand others and build an effective relationship with them. Lwin, Khoo, Lyen, \& Sim (2003, p. 197) also mentioned that interpersonal intelligence is an ability to understand and predict other's feelings, temperaments, moods, intentions and desires; and respond them appropriately. The lack of interpersonal intelligence will affect students' attitude and understanding towards others which results in more individualists and less sensitive students towards their surroundings.

In natural science teaching, learning strategies applied by the teacher strongly affect the learning effectiveness since they are related to the learning goals achievement i.e. competencies. Since a wrong pick in learning strategies leads to a decrease in learning effectivity; thus, the teacher should pay more attention to learning models or methods that he uses.

Students' learning process will be in line with specific development patterns and stages according to their ages. Those patterns and stages are systematic in a certain order and the students are unable to learn something beyond their cognitive stage. Piaget (Shaffer \& Kipp, 2010, pp. 253-277) stated that children learning process until they are able to think like adults is through four cognitive development stages, they are (1) sensorimotor that starts from birth through ages $0-2,(2)$ preoperational that starts from ages $2-7$, (3) concrete operational that starts from ages 7-11, and (4) formal operational that starts from ages 11-12 up. The fifth graders of elementary school are categorized into a concrete operational stage that occurs from ages 7-11. In this stage, the children can perform the concrete operation, demonstrate logical reasoning as long as the reasoning can be applied to concrete or specific concepts.

There are some theories related to critical thinking skill and interpersonal intelligence development. According to Duch, Groh, \& Allen (2001, p. 238), one of the ways to develop critical thinking is problem-based learning model which can challenge the students to identify, investigate and interpret things they need in solving problems. In line with Peeters \& Boddu (2016, p. 272), a foundation of critical thinking is analysis and interpretation then assessment and conclusion. Ruggiero (2012, p. 24) also explained three basic activities in critical thinking, i.e. at first, an investigation that refers to find facts, evidence, and information which can be keys to solve the problems. Secondly, an interpretation that refers to determine desired facts. Thirdly, a judgement that refers to draw a conclusion and make a decision related to the existing problems.

Savin-Baden \& Major (2004, p. 11) explained that problem-based learning model is the learning which the students must develop their metacognitive skills and are expected to use their logical reasoning to manage and solve 


\section{Jurnal Prima Edukasia, 6 (1), January 2018 -68}

Khalis Amrullah, S. Suwarjo

complex problems and finally their critical thinking skills will also be sharpened.

The next theory related to interpersonal intelligence is according to McKenzie (2005, p. 12), who stated that interpersonal intelligence can be triggered by interacting with others. Hence, the appropriate learning for interpersonal intelligence is the one that enables the students to interact and cooperate with each other as in cooperative learning. Safaria (2005, p. 24) mentioned that interpersonal intelligence has three main dimensions i.e. social sensitivity, social insight and social communication. Those three dimensions are one unity and complement each other. Hoerr, Boggeman, \& Wallach (2010, p. 10) explained that when working in a group, the students will figure out ways to cooperate, that certain steps done while cooperating are for the sake of the group's success, and that the interactive process occurred is to develop each student's interpersonal intelligence.

Slavin $(2015$, p. 2) explained that cooperative learning is a learning where the students work in small groups to help each other learn the taught subject. In the cooperative class, the students are expected to help, discuss, have a debate, evaluate new knowledge and cover up each other's weakness. Cooperative learning creates consciously and intentionally educative interaction so that the learning sources are not only from the teacher and books but also from each student that later can improve the students' interpersonal intelligence.

The improvement in students' critical thinking skill and interpersonal intelligence can occur through the use of cooperative and problem-based learning models in the teaching process. Yusof, Hassan, Jamaludin, \& Harun (2012, p. 224) defined cooperative problembased learning model as a combination of problem-based learning with cooperative learning in which it divides the students into small groups of four to six heterogenous ones and presents the groups with topics related to their daily lives providing them an an opportunity to identify, interpret and conclude the problem solving, as well as make them have a good attitude and manner towards their peers.

There are some previous studies addressing the learning model that could improve the elementary students' critical thinking skill and interpersonal intelligence. First, a study conducted by Anindyta \& Suwarjo (2014) on natural science teaching in the fifth graders of SD Santo Vincentius, East Jakarta concluded that the use of problem-based learning gave a positive and significant effect in students' critical thinking skill and self-regulation. Another study conducted by Juano \& Pardjono (2016) inferred that problem-based learning affected positively towards the fifth graders of elementary school.

A further study run by Kodariyati \& Astuti (2016) concluded that problem-based learning model affected positively and significantly towards the fifth graders' communication and problem-solving skills. When their communication skill improved, it would indirectly affect their interpersonal intelligence. Furthermore, the improvement in their problem-solving skill also gave the indirect effect on their critical thinking skill.

Another study conducted by Rakhmawati, Chamdani, \& Suryandari (2013) in the fifth graders of SD Negeri Lerep, Kebumen showed that the problem-based learning model could improve the students' critical thinking skill in a natural science subject. Furthermore, a study by Turan, Konan, Kılıç, Özvarış, \& Sayek (2012) inferred that cooperative-problem based learning model improved cooperation and achievement levels among the students in the study group. By the improvement of the group's members' cooperation, it proved that the students could act pro-social and understand the situation and social ethics, meaning that their interpersonal intelligence improved as well.

Hence, based on the previous analysis, it was necessary to conduct a study to find out whether the cooperative problem-based learning was also effective in improving the students' critical thinking skill and interpersonal intelligence if it was applied in natural science teaching whose material was a simple aircraft for the fifth graders of SDN Liang Anggang 1 South Kalimantan. The material on simple aircraft was chosen since the problem that would be solved in cooperative problem-based learning had to be contextual - related to the students' experiences, and the material on simple aircraft was closely related to the students' daily lives and experiences.

Formulated problems in this research were: (1) Is the cooperative problem-based learning model effective in improving the fifth graders' critical thinking skills? (2) Is the cooperative problem-based learning model effective in improving the fifth graders' interpersonal intelligence? (3) Is the cooperative problem-based learning model effective in 
improving the fifth graders' critical thinking skills and interpersonal intelligence?

This study aimed to find out (1) the effectivity of cooperative problem-based learning in the students' critical thinking skill; (2) the effectivity of cooperative problem-based learning in the students' interpersonal intelligence; (3) (1) the effectivity of cooperative problembased learning in the students' critical thinking skill and interpersonal intelligence.

\section{Method}

This study employed quantitative approach. It was a quasi-experiment with the pretest-posttest control group design. This study was conducted in SDN Liang Anggang 1, SDN PAndahan 1 and SDN Pandahan 2 Bati-Bati District, South Kalimantan. It was conducted in the second semester academic year 2015/2016, that was from January to March. The learning material that was taught in that semester was the simple aircraft.

The population was all the fifth graders in public elementary schools within Antasari group, Bati-Bati District, Tanah Laut Regency, South Kalimantan. The total number of public elementary schools within Antasari group were eight schools, consisting of SDN Pandahan 1, SDN Pandahan 2, SDN Liang Anggang 1, SDN Liang Anggang 2, SDN Nusa Indah 1, SDN Nusa Indah 2, SDN Ujung 1, and SDN Ujung 2.

The sample was all fifth graders in SDN Liang Anggang 1, SDN Pandahan 1, and SDN Pandahan 2. This study used simple random sampling.

By using random sampling technique, all fifth graders in SDN Liang Anggang became the experimental group (treatment would be given) and all fifth graders in SDN Pandahan 1 as the control group. While all fifth graders in SDN Ling Anggang 2 were also the experimental group that would be given treatment.

The experimental design was the pretestpostest control group from Campbell \& Stanley (1963) that was presented as follows:

Table 1. Experimental Design

\begin{tabular}{cccc}
\hline Group & Pretest & Treatment & Post-test \\
\hline $\mathrm{E}$ & $\mathrm{O}_{1}$ & $\mathrm{X}_{\mathrm{A}}$ & $\mathrm{O}_{2}$ \\
$\mathrm{C}$ & $\mathrm{O}_{3}$ & $\mathrm{X}_{\mathrm{B}}$ & $\mathrm{O}_{4}$ \\
\hline
\end{tabular}

Notes:

$\mathrm{E}$ : Experimental group

$\mathrm{C}$ : Control group

$\mathrm{O}_{1}$ : Pretest of experimental group

$\mathrm{O}_{2}$ : Posttest of experimental group
$\mathrm{O}_{3}:$ Pretest of control group

$\mathrm{O}_{4}$ : Posttest of control group

$\mathrm{X}_{\mathrm{A}}$ : Treatment for experimental group

$\mathrm{X}_{\mathrm{B}}$ : Treatment for control group

Experimental groups were those who obtained treatment by using cooperative problem-based learning. While the control group was the one who did not obtain treatment. In other words, the control group was the one that applied existing learning model that the teacher was used to teaching i.e expository.

Data collecting technique was test and scale. The test was used to find out the critical thinking and the scale were used to find out the interpersonal intelligence. In developing test and scale, a test for instrument validity was performed. This research used content and construct validity tests referring to expert judgments. Assessment towards instrument validity was based on expert judgment.

After performing validation process based on expert judgments, the instrument was tested to all fifth graders in SDN Liang Anggang 2. The test score result of the instrument was analyzed using correlation product moment from Pearson with SPSS 21 for windows whose criterion $>0,30$ (Azwar, 2015, p. 164).

From the analysis result, 5 (five) questions on critical thinking skill and 35 (thirty-five) scale items on interpersonal intelligence were valid since their scores $>0.03$. Instrument items must be valid, and besides, the instrument must be also reliable. The instrument reliability test in this research used a formula Cronbach alpha (Azwar, 2015, p. 67) with SPSS 21 for windows program and obtained the result that both instruments were reliable with score 0,827 in critical thinking skill and 0,978 in interpersonal intelligence.

Data analysis technique used two kinds of statistics, descriptive and inferential ones. Descriptive statistics used to present the data which had been collected through pretest and post-test results in the students' critical thinking skills either from the experimental groups or the control group. The data were presented in tables covering mean, deviation standard, variance, minimum and maximum scores. This descriptive statistics calculation used Ms Excel and SPSS 21.0 for windows programs.

Related to inferential statistics used in this research, the data analysis technique applied was the independent sample t-test and MANOVA. The independent sample t-test was used to find out whether there was a significant difference in 
mean of experimental groups and the control group, while MANOVA was used to see an effect of cooperative problem-based learning implementation in the students' critical thinking skills and interpersonal intelligence.

Statistical hypotheses tested in this research used t-test analysis technique as follows.

Hypothesis 1:

Ho: $\mu A_{1} \leq \mu A_{2}$

Ha: $\mu A_{1}>\mu A_{2}$

Hypthesis 2:

Ho: $\mu B_{1} \leq \mu B_{2}$

Ha: $\mu B_{1}>\mu B_{2}$

Notes:

$\mu A_{1}$ : Mean in the students' critical thinking skills who enrolled in the natural science subject learning using cooperative problem-based learning model

$\mu A_{2}$ : Mean in the the students' critical thinking skills who enrolled in the natural science subject learning using expository learning model

$\mu B_{1}$ : Mean in the students' interpersonal intelligence who enrolled in the natural science subject learning using cooperative problem-based learning model

$\mu B_{2}$ : Mean in the the students' interpersonal intelligence who enrolled in the natural science subject learning using expository learning model

The independent t-test sample was calculated using SPSS 21.00 for windows program. The criteria for determining whether the null hypothesis should be rejected or retained was if the sig. value was lower than 0,05 the null hypothesis was rejected, meaning that there was a significant difference in mean between the experimental groups and the control group.

Statistical hypotheses using MANOVA were as follows.
Ho: There was no effect of cooperative problembased learning model implementation in the students' critical thinking skills and interpersonal intelligence

Ha: There was an effect of cooperative problembased learning model implementation on the students' critical thinking skills and interpersonal intelligence

The criteria for hypothesis testing was the null hypothesis was rejected if the sig. value was lower than $(<) 0,05$ by using SPSS 21.0 for windows.

To use independent sample t-test analysis technique, assumptions of normality and of homogeneity of variances are required to be met. Normality test is used to determine whether data from each variable are normally distributed or not. Normality test was done for pretest in both the experimental groups and the control group. The normality test from Kolmogorov Smirnov in SPSS 21.0 for windows was used in this research. Proposed hypotheses were as follows.

Ho: Data were normally distributed.

Ha: Data were not normally distributed.

The criteria to measure the population normality in this research was the null hypothesis was accepted if the sig value was more than $(>) \propto 0,05$.

Homogeneity test aims to determine whether the research subjects are from the homogenous population or not. The homogeneity test was done for pretest data. Levene homogeneity was used in this research. Proposed hypotheses were as follows.

Ho: Variable variances were homogenous

Ha: Variable variances were not homogenous (heterogenous)

The criteria to measure the variance homogeneity in this research was the null hypothesis was accepted if the sig value was more than $(>) \propto 0,05$.

Table 2. Data Summary of The Students' Critical Thinking Skills and Interpersonal Intelligence

\begin{tabular}{cccccccc}
\hline \multirow{2}{*}{ Variable } & \multirow{2}{*}{ Description } & \multicolumn{2}{c}{ Experimental Class 1 } & \multicolumn{2}{c}{ Experimental Class 2 } & \multicolumn{2}{c}{ Control Class } \\
\cline { 3 - 8 } & & Pretest & Post-test & Pretest & Post-test & Pretest & Post-test \\
\hline \multirow{2}{*}{ Critical Thinking } & 4,52 & 13,82 & 4,00 & 14,07 & 4,36 & 4,82 \\
Skills & Standard of Deviation & 2,063 & 1,793 & 2,197 & 1,799 & 2,205 & 1,991 \\
& Maximum Score & 8 & 17 & 8 & 17 & 8 & 8 \\
Interpersonal & Minimum Score & 0 & 10 & 0 & 10 & 0 & 1 \\
Intelligence & Mean & 68,67 & 119,97 & 67,63 & 119,7 & 68,55 & 69,91 \\
& Standard of Deviation & 5,218 & 7,892 & 4,679 & 7,479 & 5,136 & 8,259
\end{tabular}


Jurnal Prima Edukasia, 6 (1), January 2018 -71

Khalis Amrullah, S. Suwarjo

\begin{tabular}{llllllc} 
Maximum Score & 79 & 133 & 78 & 130 & 78 & 3 \\
Minimum Score & 60 & 104 & 59 & 104 & 59 & 55 \\
\hline
\end{tabular}

\section{Results and Discussion}

Data of critical thinking skills and interpersonal intelligence consisted of pretest and posttest data from the control group and experimental groups. Pretest data showed the prior condition of the students' critical thinking skills and interpersonal intelligence, either in the control group or the experimental groups before being given treatment. Posttest data showed the condition of the students' critical thinking skills and interpersonal intelligence, either in the control group or the experimental groups after being given treatment. The data were presented in Table 2.Based on the presented Table 1, it could be seen that pretest scores mean of the students' critical thinking in the experimental class I was 4.52 and the maximum score was 8 and the minimum one was 0 . The pretest scores mean of the students' critical thinking in the experimental class II was 4 and the maximum score was 8 and the minimum one was 0 . The pretest scores mean of the students' critical thinking in the control class was 4.36 and the maximum score was 8 and the minimum one was 0 . After being given treatment, the posttest scores mean of the students' critical thinking in the experimental class I was 13.82 and the maximum score was 17 and the minimum one was 10. The posttest scores mean of the students' critical thinking in the experimental class II was 14.07 and the maximum score was 17 and the minimum one was 10 . The posttest scores mean of the students' critical thinking in the control class was 4,82 and the maximum score was 8 and the minimum one was 1 .

The pretest scores mean of the students' interpersonal intelligence in the experimental class I was 68,67 and the maximum score was 79 and the minimum one was 60 . The pretest scores mean of the students' interpersonal intelligence in the experimental class II was 67.63 and the maximum score was 78 and the minimum one was 59 . The pretest scores mean of the students' interpersonal intelligence in the control class was 68.55 and the maximum score was 78 and the minimum one was 59. After being given treatment, the posttest scores mean of the students' interpersonal intelligence in the experimental class I was 119.97 and the maximum score was 133 and the minimum one was 104. The posttest scores mean of the students' interpersonal intelligence in the experimental class II was 119.7 and the maximum score was 130 and the minimum one was 104 . The posttest scores mean of the students' interpersonal intelligence in the control class was 69.91 and the maximum score was 83 and the minimum one was 55.

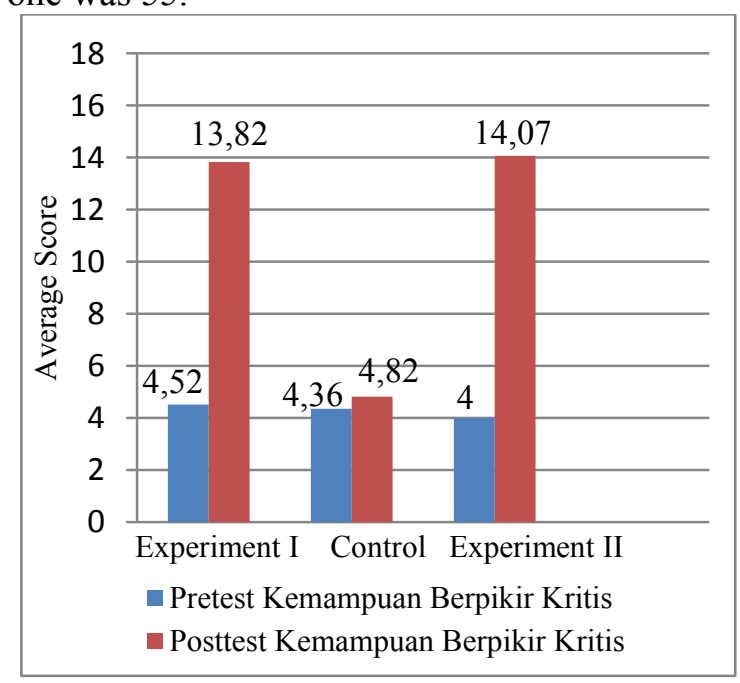

Figure 1. The bar chart reflecting a comparison of the pre-test and post-test means scores in the students' critical thinking skills for the control

group and the experimental groups

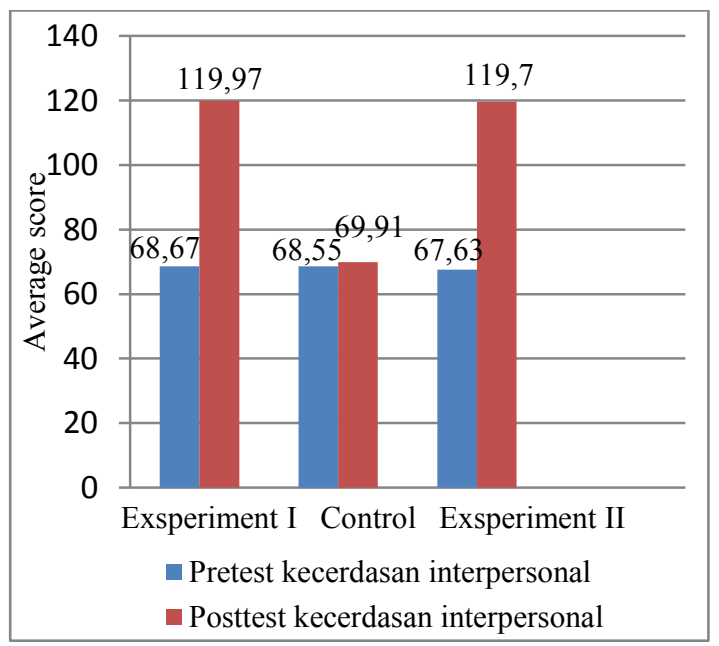

Figure 2. The bar chart reflecting a comparison of the pre-test and post-test means scores in the students' interpersonal intelligence for the control group and the experimental groups

The Figure 1 reflecting a comparison of the pre-test and post-test means scores in the students' critical thinking skills for the control group and the experimental groups. Based on the Figure 1, it can be seen that the pre-test and post-test mean scores in the students' critical 
thinking skills for the experimental group I increased 9,3; the control class increased 0,46; and, the experimental group II increased 10,07.

The Figure 2 reflecting a comparison of the pre-test and post-test means scores in the students' interpersonal intelligence for the control group and the experimental groups. Based on the Figure 2, it can be seen that the pre-test and post-test mean scores in the students' interpersonal intelligence for the experimental group I increased 51.3; the experimental group II increased 52.07; and, the control class increased 1.36. By comparing the score increase in the experimental groups and the control group, it could be concluded that the experimental groups' scores increased higher than the control group.

Normality and of homogeneity of variances tests were conducted as a prerequisite for the independent sample t-test. The normality test was used to determine whether data from each variable were normally distributed or not. In doing it, the researcher used KolmogrovSmirnov in SPSS 21.0 for windows. Proposed hypotheses were as follows.

Ho: normally distributed

Ha: not normally distributed

If the sig. value was higher than determined alpha i.e 5\%, the null hypothesis would be accepted. On the contrary, if the sig. value was lower than determined alpha, the null hypothesis would be rejected. The normality test result of critical thinking skill and interpersonal intelligence variables in the control group and experimental groups was presented in Table 3 .

Based on Table 3, it could be seen that the sig. value of the pre-test and post-test in the students' critical thinking skills and interpersonal intelligence for the experimental groups and control group was higher $(>)$ than determined alpha 0.05. Therefore, the null hypothesis was retained, meaning that all data were normally distributed.

Homogeneity test was used to determine whether the research subjects were from the homogenous population or not. In performing the homogeneity test, the researcher used Levene Statistic in SPSS 21.0 for windows. Proposed hypotheses were as follows.

Ho: Variable variances were homogenous.

Ha: Variable variances were not homogenous (heterogeneous)

If the sig. value was higher than determined alpha i.e 5\%, the null hypothesis would be accepted. On the contrary, if the sig. value was lower than determined alpha, the null hypothesis would be rejected. The homogeneity test result of critical thinking skill and interpersonal intelligence variables in the control group and experimental groups were presented in Table 4.

Based on Table 4, it could be seen that the sig. value of the pre-test and post-test in the students' critical thinking skills and interpersonal intelligence for the experimental groups and control group was higher $(>)$ than determined alpha 0.05 . Therefore, the null hypothesis was retained, meaning that all variable variances were homogeneous.

Based on the results of inferential statistics prerequisite tests above, it could be concluded that the data were normally distributed and the variable variances among those three groups were homogeneous. Thus, the data had met the condition to be analyzed. The appropriate statistical tests to test the hypotheses were Independent Sample t-test, then later MANOVA.

Table 3. Data summary of normality test for the experimental classes and the control class

\begin{tabular}{|c|c|c|c|c|}
\hline \multirow{2}{*}{ Scores } & \multirow{2}{*}{ Classes } & \multicolumn{2}{|c|}{$\begin{array}{l}\text { Kolgomorov-Smirnov } \\
\text { Significance }\end{array}$} & \multirow{2}{*}{ Notes } \\
\hline & & $\begin{array}{c}\text { Critical } \\
\text { Thinking Skill }\end{array}$ & $\begin{array}{c}\text { Interpersonal } \\
\text { Intelligence }\end{array}$ & \\
\hline \multirow{3}{*}{ Pretest } & Experimental Class I & 0.110 & 0.198 & Sig. $>0.05=$ normal \\
\hline & Experimental Class II & 0.125 & 0.161 & Sig. $>0.05=$ normal \\
\hline & Control Class & 0.181 & 0.144 & Sig. $>0.05=$ normal \\
\hline \multirow{3}{*}{ Post-test } & Experimental Class I & 0.07 & 0.147 & Sig. $>0.05=$ normal \\
\hline & Experimental Class II & 0.075 & 0.200 & Sig. $>0.05=$ normal \\
\hline & Control Class & 0.087 & 0.200 & Sig. $>0.05=$ normal \\
\hline
\end{tabular}

Table 4. Data summary of homogeneity test for the experimental classes and the control class

Classes
Kolgomorov-Smirnov Significance

Critical Thinking Skill Critical Thinking Skill

Notes 
Jurnal Prima Edukasia, 6 (1), January 2018 -73

Khalis Amrullah, S. Suwarjo

\begin{tabular}{llll}
\hline Experimental Class I and Control & 0.667 & 0.976 & Sig. $>0.05$ \\
Experimental Class II and Control & 0.981 & 0.445 & Sig. $>0.05$ \\
\hline
\end{tabular}

Table 5. Data summary of independent sample t-test for the students' critical thinking skills

\begin{tabular}{cc}
\hline Data & Sig. \\
\hline Posttest Experimental Class I and Control & $0.000<0.05$ \\
Posttest Experimental Class II and Control & $0.000<0.05$ \\
\hline
\end{tabular}

Table 6. Summary of t-test result of the students' interpersonal intelligence

\begin{tabular}{cc}
\hline & Data \\
\hline Post-test the experimental group I and the control group & $0.000<0.05$ \\
Post-test the experimental group II and the control group & $0.000<0.05$ \\
\hline
\end{tabular}

Table 7. Data summary of MANOVA result of the post-test in the experimental class $i$ and the control class

\begin{tabular}{lcc}
\hline \multicolumn{1}{c}{ Data } & Sig. & Note \\
\hline $\begin{array}{l}\text { Post-test in the students' critical thinking skills for the experimental class I and the control class } \\
\text { Post-test in the students' interpersonal intelligence for the experimental class I and the control } \\
\text { class }\end{array}$ & 0.000 & $<0.05$ \\
\hline
\end{tabular}

Table 8. Data Summary of MANOVA Result of the Post-test on the experimental class II and the control class

\begin{tabular}{lcc}
\hline \multicolumn{1}{c}{ Data } & Sig. & Note \\
\hline $\begin{array}{l}\text { Post-test in the students' critical thinking skills for the experimental class II and the control } \\
\text { class }\end{array}$ & 0.000 & $<0.05$ \\
$\begin{array}{l}\text { Post-test in the students' interpersonal intelligence for the experimental class II and the control } \\
\text { class }\end{array}$ & $0.000<0.05$ \\
\hline
\end{tabular}

The independent sample t-test was used to determine whether there was a significant difference in means of the experimental groups and the control group. T-test analysis hypotheses were as follows.

Hyphothesis 1:

Ho: $\mu A_{1} \leq \mu A_{2}$

Ha: $\mu A_{1}>\mu A_{2}$

Notes:

$\mu A_{1}$ : Mean in the students' critical thinking skills who enrolled in the natural science subject learning using cooperative problembased learning model

$\mu A_{2}$ : Mean in the the students' critical thinking skills who enrolled in the natural science subject learning using expository learning model

The criteria for determining whether the null hypothesis should be rejected or retained was if the sig. value was lower than 0.05 the null hypothesis was rejected, meaning that there was a significant difference in mean of the experimental groups and the control group. Ttest result in the students' critical thinking skills for the experimental groups and the control group was presented in Table 5 .
From Table 5, it could be concluded that significant value of post-test in the experimental groups I and the control group was 0.000. It was less than $(<) 0.05$ so the null hypothesis was rejected and the alternative hypothesis was retained. T-test result stated that there was a significant difference in means of the students' critical thinking skills, which means of the experimental group I was higher than the control group.

Then it also could be seen that significant value of post-test in the experimental groups II and the control group was 0.000 . It was less than $(<) 0.05$ so the null hypothesis was rejected and the alternative hypothesis was retained. T-test result stated that there was a significant difference in means of the students' critical thinking skills, in which means of the experimental group II was higher than the control group.

Hypothesis 2:

Ho: $\mu B_{1} \leq \mu B_{2}$

Ha: $\mu B_{1}>\mu B_{2}$

Notes:

$\mu B_{1}$ : Mean in the students' interpersonal intelligence who enrolled in the natural science subject learning using cooperative problem-based learning model 
Jurnal Prima Edukasia, 6 (1), January 2018 -74

Khalis Amrullah, S. Suwarjo

$\mu B_{2}$ : Mean in the the students' interpersonal intelligence who enrolled in the natural science subject learning using expository learning model

The t-test result of the students' interpersonal intelligence in the experimental groups and the control group was presented in Table 6. From Table 6, it could be concluded that significant value of post-test in the experimental groups I and the control group was 0.000 . It was less than $(<) 0.05$ so the null hypothesis was rejected and the alternative hypothesis was retained. T-test result stated that there was a significant difference in means of the students' interpersonal intelligence, which means of the experimental group I was higher than the control group.

Then it also could be seen that significant value of post-test in the experimental groups II and the control group was 0.000 . It was less than $(<) 0.05$ so the null hypothesis was rejected and the alternative hypothesis was retained. T-test result stated that there was a significant difference in means of the students' interpersonal intelligence, which means of the experimental group II was higher than the control group.

MANOVA was performed to determine the effect of cooperative problem-based learning implementation in the students' critical thinking skills and interpersonal intelligence.Statistical hypotheses in MANOVA were as follows.

Hypothesis 1

Ho: There was no effect of cooperative problembased learning model implementation in the students' critical thinking skills and interpersonal intelligence

Ha: There was an effect of cooperative problembased learning model implementation on the students' critical thinking skills and interpersonal intelligence

MANOVA result of the post-test of the students' critical thinking skills and interpersonal intelligence in the experimental group I and the control group was presented in Table 7 .

From Table 7, it could be seen that significant value of post-test in the students' critical thinking skills for the experimental group I and the control group was 0.000 . It was less than $(<) 0.05$ so the null hypothesis was rejected and the alternative hypothesis was retained. It could be concluded that there was a positive effect of the cooperative problem-based learning model implementation in the students' critical thinking skills for the experimental group I.

Then it could be seen that the significant value of post-test in the students' interpersonal intelligence for the experimental group I and the control group was 0.000 . It was less than $(<)$ 0.05 so the null hypothesis was rejected and the alternative hypothesis was retained. It could be concluded that there was a positive effect of the cooperative problem-based learning model implementation in the students' interpersonal intelligence for the experimental group I.

The MANOVA result of the post-test in the students' critical thinking skills and interpersonal intelligence for the experimental group II and the control group was presented in Table 8.

From Table 8, it could be seen that significant value of post-test in the students' critical thinking skills for the experimental group II and the control group was 0.000 . It was less than $(<) 0.05$ so the null hypothesis was rejected and the alternative hypothesis was retained. It could be concluded that there was a positive effect of the cooperative problem-based learning model implementation in the students' critical thinking skills for the experimental group II.

Then it could be seen that the significant value of post-test in the students' interpersonal intelligence for the experimental group II and the control group was 0.000 . It was less than $(<)$ 0.05 so the null hypothesis was rejected and the alternative hypothesis was retained. It could be concluded that there was a positive effect of the cooperative problem-based learning model implementation in the students' interpersonal intelligence for the experimental group II.

Based on findings and the data analysis, it could be concluded that the implementation of cooperative problem-based learning in the natural science subject learning was effective for improving the fifth graders' critical thinking skills and interpersonal intelligence compared to the implementation of the expository model.

The first finding related to the improvement of the students' critical thinking skills was in line with Probst $(2015$, p. 238) stating that a way to develop the student's critical thinking is through a learning that can challenge the students to investigate their own needs in solving problems, interpret information they have found, and take a necessary action to reach a conclusion. 
Jurnal Prima Edukasia, 6 (1), January 2018 -75

Khalis Amrullah, S. Suwarjo

The improvement in the students' critical thinking skills by the cooperative problem-based learning model could occur since this model provided a problem that had to be solved by the students. It was in line with Forawi (2016, p. 7) who stated that the critical thinking skill can be developed by implementing learning models that require reasoning elements based on the students' intellectual standard. One of them is by proposing a problem that needs a right solution and appropriates with the students' daily lives. The cooperative problem-based learning provides the problem that is related to the students' daily lives so that it provides an opportunity for the students to identify the problem, interpret evidence of information that have been found, and draw a conclusion of the right solution to solve the problem being faced. In the end, the students' critical thinking skills are improved.

Besides the critical thinking skills, the second finding in this research revealed that the implementation of cooperative problem-based learning in the natural science subject learning was also effective in improving the students' interpersonal intelligence. It was in line with deNevers (2014) stating that through a problembased learning scenario the students can improve their interpersonal intelligence by having a small group discussion, communicating politely among the group members, cooperating with each other, helping each group's member in solving the problem.

By having the group work in learning that used cooperative problem-based learning, a positive interaction among the students could occur more frequently. Having more interactions, the students could show more empathy for their friends, admit their own weaknesses, and listen to their friends' opinions much better so that their interpersonal intelligence was improved. It was appropriate with McKenzie (2005, p. 12) stating that the interpersonal intelligence can be triggered by having more positive interactions with other people.

Implementing the cooperative problembased learning model in the natural science subject covered some important stages. The first phase was by providing the students a daily life problem could trigger them to do scientific activities such as observation, investigate, interpret, and find a solution to solve the problem. The next phase was organizing the students into cooperative groups, placing them into small groups of 4-6 students who were heterogeneous, giving them an opportunity to work together in solving the problem, listen to their friends' opinions, communicate politely with their friends.Thus, this process indirectly trained the students to act proportionally, listened to their friends' ideas, communicated politely, showed empathy, raised self-awareness, understood the social situation and ethic, solved the problem, and at the end, it improved the students' interpersonal intelligence. Then the following phase was analyzing and evaluating the problem-solving process. In this phase, the teacher guided the students a proper way to solve the problem without restricting the students' own ideas.

The group receiving treatment which was cooperative problem-based learning model in the natural science subject different showed different descriptive statistics results than the group having expository learning model. The differences were shown from the pre-test and post-test mean scores in the students' critical thinking skills and interpersonal intelligence. Pre-test data showed that at the beginning all groups' skills were almost similar. The pre-test mean score in the critical thinking skill for the experimental class I was 4.52; the experimental class II was 4.00; and, the control class was 4.36. The pre-test mean score in the interpersonal intelligence for the experimental class I was 68.67; the experimental class II was 67.63: and the control class was 68.55.

The post-test data in the critical thinking skills and interpersonal intelligence showed different mean scores. The post-test mean scores in the critical thinking skills for the experimental class I was 13.82; the experimental class II was 14.07; and, the control class was 4.82 . While the post-test mean scores in the interpersonal intelligence for the experimental class I was 119.97; the experimental class II was 119.70; and, the control class was 69.91 .

Based on the previous discussion of mean scores in the students' critical thinking skills and interpersonal intelligence, it could be seen that the post-test mean scores in the experimental groups were significantly higher than the control group. It revealed the implementation of cooperative problem-based learning in the natural science subject was proven to effectively improve the students' critical thinking skills and interpersonal intelligence in the fifth grade of SDN Liang Anggang 1 and Pandahan 2, BatiBati District, South Kalimantan. 
The improvement in the students' critical thinking skills might lend support previous study results conducted by Pricillia (2014) concluding that the implementation of problembased learning model positively and significantly affected the critical thinking skill in the natural science subject, and also Juano \& Pardjono (2016) concluding that the problembased learning would affect positively to the fifth graders' critical thinking skills.

The improvement in the students' interpersonal intelligence supported the study conducted by Turan et al. (2012) concluding that the cooperative problem-based learning model in the study group improved each member's achievement and cooperation level. The improvement of each member's cooperation proved that the students were able to be prosocial and understand a social situation and ethics meaning that their interpersonal intelligence also improved. A further study conducted by Kodariyati \& Astuti (2016) concluded that problem-based learning model had a positive and significant effect on the fifth graders' communication and problem-solving skills. The improvement of communication skills resulted in the improvement of the students' interpersonal intelligence, and the improvement of problem-solving skills indirectly affected the students' critical thinking skills as well.

Based on the discussion, it could be inferred that the implementation of cooperative problem-based learning model in the natural science subject was effective in improving the students' critical thinking skills and interpersonal intelligence. It supported exiting theories and previous studies related to the implementation pf cooperative problem-based learning model in the learning process.

\section{Conclusion}

Based on the results and discussion mentioned previously, it could be concluded: firstly, the implementation of cooperative problem-based learning model in the natural science subject was effective in improving the students' critical thinking skills. Secondly, the implementation of cooperative problem-based learning in the natural science subject was effective in improving the students' interpersonal intelligence. Thirdly, the implementation of cooperative problem-based learning in the natural science subject was effective in improving the students' critical thinking skills and interpersonal intelligence for the fifth graders in SDN Liang Anggang 1 and Pandahan 2, Bati-Bati District South Kalimantan.

Based on the findings, this research is expected to contribute positively to education, especially the natural science subject. Some suggestions are made to improve the education more, such as (1) For teachers, the cooperative problem-based learning can be used as an alternative to the natural science subject learning, (2) For further researchers, similar meeting gap in presenting materials either in the experimental group or the control one should be paid more attention in order to gain more accurate difference in the tested results.

\section{References}

Anindyta, P., \& Suwarjo, S. (2014). Pengaruh problem based learning terhadap keterampilan berpikir kritis dan regulasi diri siswa kelas V. Jurnal Prima Edukasia, 2(2), 209-222. https://doi.org/10.21831/jpe.v2i2.2720

Azwar, S. (2015). Reliabilitas dan validitas. Yogyakarta: Pustaka Pelajar.

Campbell, D. T., \& Stanley, J. C. (1963). Experimental and quasi-experiment al designs for research. Bosston, MA: Houghton Mifflin Company.

deNevers, D. M. (2014). Interpersonal intelligence and problem-based learning. Department of Education Dordt College.

Duch, B. J., Groh, S. E., \& Allen, D. E. (2001). The power of problem-based learning: $A$ practical \&quot;how to\&quot; for teaching undergraduate courses in any discipline. Virginia: Stylus Pub.

Fisher, A. (2001). Critical thinking: An introduction. Cambridge: Cambridge University Press.

Forawi, S. A. (2016). Standard-based science education and critical thinking. Thinking Skills and Creativity, 20, 52-62. https://doi.org/10.1016/J.TSC.2016.02.00 5

Gardner, H. (2011). Frames of mind: The theory of multiple intelligences. New York, N.Y.: Basic Books.

Hoerr, T. R., Boggeman, S., \& Wallach, C. (2010). Celebrating every learner: Activities and strategies for creating a multiple intelligences classroom. San Fransisco: Jossey-Bass. 
Juano, A., \& Pardjono, P. (2016). Pengaruh pembelajaran problem posing terhadap kemampuan berpikir kritis dan komunikasi matematis siswa kelas V SD. Jurnal Prima Edukasia, 4(1), 46. https://doi.org/10.21831/jpe.v4i1.7801

Kodariyati, L., \& Astuti, B. (2016). Pengaruh model PBL terhadap kemampuan komunikasi dan pemecahan masalah matematika siswa kelas V SD. Jurnal Prima Edukasia, 4(1), 93. https://doi.org/10.21831/jpe.v4i1.7713

Lwin, M., Khoo, A., Lyen, K., \& Sim, C. (2003). How to multiply your child's intelligence : a practical guide for parents of seven-year-olds and below. Prentice Hall.

McKenzie, W. (2005). Multiple intelligences and instructional technology. Washington D.C.: International Society for Technology in Education.

Peeters, M. J., \& Boddu, S. H. S. (2016). Assessing development in critical thinking: One institution's experience. Currents in Pharmacy Teaching and Learning, $\quad 8(3), \quad 271-278$. https://doi.org/10.1016/J.CPTL.2016.02.0 07

Probst, B. (2015). Critical thinking in clinical assessment and diagnosis. New York, N.Y.: Springer .

Rakhmawati, Y., Chamdani, M., \& Suryandari, K. C. (2013). Penerapan Model PBL dalam Peningkatan Berpikir Kritis IPA Siswa Kelas V SD. Kalam Cendekia PGSD Kebumen, 3(2). Retrieved from http://jurnal.fkip.uns.ac.id/index.php/pgsd kebumen/article/view/1908/1412

Ruggiero, V. R. (2012). Beyond feelings: A guide to critical thinking. New York, N.Y.: McGraw-Hill.

Safaria, T. (2005). Interpersonal intelligence: Metode pengembangan kecerdasan interpersonal anak. Yogyakarta: Amara Books.

Savin-Baden, M., \& Major, C. H. (2004). Foundations of problem-based learning. Cornwall: Society for Research into Higher Education \& Open University Press.

Shaffer, D. R., \& Kipp, K. (2010). Developmental psychology: Childhood and adolescence. Belmont: Wadsworth Cengage Learning.

Slavin, R. E. (2015). Cooperative learning: Theory, research, and practice. Allyn and Bacon.

Trilling, B., \& Fadel, C. (2009). 21st century skills: learning for life in our times. San Francisco: Jossey-Bass.

Turan, S., Konan, A., Kılıç, Y. A., Özvarış, Ş. B., \& Sayek, İ. (2012). The effect of problem-based learning with cooperativelearning strategies in surgery clerkships. Journal of Surgical Education, 69(2), 226-230. https://doi.org/10.1016/J.JSURG.2011.07. 010

Yusof, K. M., Hassan, S. A. H. S., Jamaludin, M. Z., \& Harun, N. F. (2012). Cooperative problem-based learning (CPBL): Framework for integrating cooperative learning and problem-based learning. Procedia - Social and Behavioral Sciences, 56, 223-232. https://doi.org/10.1016/J.SBSPRO.2012.0 9.649 